\title{
Physicochemical characteristics and antioxidant activities of laver cultivars harvested at different times
}

\author{
Won $\mathrm{Kim}^{1,2 *}$, Jin Young Kim ${ }^{1}$, Su Ji Jeong ${ }^{1}$, Ho Chul Yang${ }^{1}$, Jeong-Yong Cho ${ }^{2 *}$ \\ ${ }^{1}$ Drug Chemistry Division, Jeollanamdo Institute of Health and Environment, Muan 58568, Korea \\ ${ }^{2}$ Department of Integrative Food, Bioscience and Biotechnology, Chonnam National University, Gwangju 61186, Korea
}

\section{김의 품종 및 채취시기별 성분 및 항산화 특성 \\ 김원 ${ }^{1,2 *}$. 김진영 ${ }^{1} \cdot$ 정수지 $^{1} \cdot$ 양호철 $^{1} \cdot$ 조정용 ${ }^{2 *}$ \\ ${ }^{1}$ 전라남도보건환경연구원 약품화학과, ${ }^{2}$ 전남대학교 융합식품바이오공학과}

\begin{abstract}
The aim of this study was to compare the physicochemical characteristics and antioxidant activities of Pyropia dentata harvested in November (PD11), Pyropia seriata harvested in December (PS12), and Pyropia yezoensis harvested in December (PY12), January (PY01), or March (PY03). Total amino acid content (mg/100 g dry wt.) was high: PY01 $(41,009.52)>$ PY12 (40,914.26) > PS12 $(35,720.29)>$ PD11 (33,762.75) > PY03 (32,906.54). The major minerals within the three laver cultivars were $\mathrm{Ca}, \mathrm{K}, \mathrm{Mg}$, and $\mathrm{Na}$. PD11 exhibited the highest contents of shinorine (2,089.84 $\mathrm{mg} / 100 \mathrm{~g}$ dry wt.) and porphyra-334 $(3,127.96 \mathrm{mg} / 100 \mathrm{~g}$ dry wt.), which are mycosporine-like amino acids. Of the PY samples harvested at different times, PY03 exhibited the highest contents of shinorine $(19.00 \mathrm{mg} / 100 \mathrm{~g}$ dry wt.) and porphyra-334 (438.31 mg/100 g dry wt.). The total phenol content was higher in PD11 (702.99 $\mathrm{mg}$ tannic acid equivalent/100 g) than those in the other samples. PD11 had the highest 2,2'-azino-bis(3-ethylbenzothiazoline-6-sulfonic acid radical-scavenging and ferric reducing antioxidant activities. The results provide basic information regarding the physicochemical characteristics and antioxidant activities of laver cultivars harvested at different times.
\end{abstract}

Keywords : laver, Pyropia yezoensis, Pyropia seriata, Pyropia dentata, antioxidant activity

\section{Introduction}

Laver (Pyropia spp.) is the most popular marine red algae that is widely consumed in Korea, along with Unaria pinnatifida and Saccharina japonica. Laver has been described as "sea clothes" in Gyeongsangdo Jiriji (14241425), and cultivated since the late 1400s (Bae et al., 1991). In South Korea, laver is generally cultivated in the Southwestern coastal areas in the winter from November to
March, and approximately 610,000 tons of laver are produced in 2019, which costs about 560 billion KRW. The main varieties of laver produced in Korea are Pyropia tenera, Pyropia yezoensis, Pyropia seriata, and Pyropia dentata (Lee et al., 2017). Raw laver is used in soups, salads, and braised dishes or processed as several food products such as dried laver, roasted laver, laver snacks, and seasoned laver to be consumed as side dishes or snacks (Lee et al., 1987).

*Corresponding author. Won Kim. E-mail : one6546@korea.kr, Phone :+82-61-240-5283, Fax : +82-61-240-5285

Jeong-Yong Cho. E-mail : jyongcho17@jnu.ac.kr, Phone : +82-62-530-2143, Fax : +82-62-530-2149

Received 14 June 2021; Revised 29 July 2021; Accepted 09 August 2021.

Copyright (c) The Korean Society of Food Preservation.

This is an Open Access article distributed under the terms of the Creative Commons Attribution Non-Commercial License (http://creativecommons.org/licenses/by-nc/4.0) which permits unrestricted non-commercial use, distribution, and reproduction in any medium, provided the original work is properly cited. 
Laver is known to be a rich source of fibers, including porphyrin, minerals such as calcium, magnesium, and potassium (Park et al., 2000), and amino acids, including betaine, taurine, aspartic acid, and glutamic acid, but its lipid content is relatively low $(<2 \%)$ compared to proteins or carbohydrates (Park et al., 2000; Yoshie et al., 1993). Research has shown that it is enriched in lipids especially eicosapentaenoic acid (EPA), which could lower blood cholesterol concentration (Kwon et al., 2018). In addition, mycosporine-like amino acids (MAAs), which are found in marine organisms, are reported to have excellent antioxidant activities and skin protective effects by blocking ultraviolet rays, and porphyra-334 among them has been found in laver (Ying et al., 2019). Many studies have documented the health benefits of laver, including prevention of arthrosclerosis (Inoue et al., 2009), cardiovascular disease (Tsuge et al., 2004), and Alzheimer's disease (Liu et al., 2019; Mohibbullah et al., 2016), and bone diseases (Ueno et al., 2018), antihypertension (Ren et al., 1994; Qu et al., 2010), anti-cancer (He et al., 2019; Kwon et al., 2006; Yu et al., 2015), antioxidant (Zhang et al., 2009; Zhao et al., 2006), antiinflammatory (Yanagido et al., 2018), and anti-diabetes effects (Chaoet al., 2014; Kitano et al., 2012). With the growing awareness of the health functionality and palatability of laver, demands are steadily rising not only in East Asia but also in Southeast Asia, Europe, and United States. The palatability and health functionality of laver are attributable to the array of constituents of laver. Recently, several studies have investigated the quality properties of laver according to variety, harvest time, and production region (Beak et al., 2019; Kim et al., 2014; Shin et al., 2013), changes in quality during processing and storage (Jo et al., 1995; Son et al., 2014), and the quality characteristics of seasoned laver (Jeon et al., 2008; Seo et al., 2007). Moreover, the nutritional composition and bioactive compounds content of the laver vary greatly according to the variety, cultivation, harvest time, and oceanic conditions. Thus, more systematic studies are needed to examine the quality characteristics of laver.

In recent, three laver varieties are widely cultivated in Jeonnam, the primary region of laver production in Korea. $P$. dentata is produced from November to December, $P$. yezoensis in December, and P. seriata from December to March. Thus, this study aims to present basic data for laver processing by comparing the physicochemical characteristics and antioxidant activities of the specimens of five varieties harvested at different times, including $P$. dentata, $P$. seriata, and $P$. yezoensis.

\section{Materials and method}

\section{Experimental materials and reagents}

The laver used in this experiment was provided by Jeollanam-do Institute of Ocean \& Fisheries Science, Haenam office. $P$. dentata was harvested in November 2019 in Imhado, Haenam, and $P$. seriata was harvested in December 2019 in Imhado, Haenam. P. yezoensis was harvested in December 2019 and January and March 2020 in Eoran, Haenam. The samples were freeze-dried (PVTFD50R, Ilsin, Dongducheon, Korea) and stored at $-40^{\circ} \mathrm{C}$ before analysis. The Folin-Ciocalteu's phenol reagent, sodium carbonate $\left(\mathrm{Na}_{2} \mathrm{CO}_{3}\right)$, tannic acid, 2,2'-azino-bis(3ethylbenzothiazoline-6-sulfonic acid) $\left(\mathrm{ABST}^{+}\right)$, potassium persulfate, 2,4,6-tris(2-pyridyl)-S-triazine (TPTZ), iron (II) sulfate $\left(\mathrm{FeSO}_{4}\right)$, and ferric chloride hexahydrate were purchased from Sigma-Aldrich Chemical Co. (St. Louis, MO, USA). Mycosporine-like amino acids (shinorine and porphyra-334) used in this study were isolated from laver at our laboratory. Other organic solvents and reagents were high performance liquid chromatography (HPLC) grade or guaranteed reagent.

\section{Total amino acid content}

Total amino acid content was analyzed using the protocol used by Seo et al. (2007). $10 \mathrm{~mL}$ of $6 \mathrm{~N}$ hydrogen chloride $(\mathrm{HCl})$ was added to $50 \mathrm{mg}$ of freeze-dried laver, flushed with nitrogen gas, and heated at $105^{\circ} \mathrm{C}$ for $24 \mathrm{~h}$ using a heating block. The mixture was then filtered using a $3 \mathrm{G}-4$ glass filter, and the filtrate was concentrated under reduced pressure using a rotary vacuum evaporator $(\mathrm{N}-1200 \mathrm{~B}$, Eyela, Tokyo, Japan). The concentrate was dissolved with sodium $10 \mathrm{~mL}$ of citrate buffer solution $(\mathrm{pH} 2.2)$, filtered through a $0.2 \mu \mathrm{m}$ membrane filter (Satorius Stedim Biotech, Goettingen, Germany), and analyzed using an automated amino acid analyzer (S433-H SYKAM, Eresing, Germany) equipped with a cation separation column (LCA K06/Na, $4.6 \times 150 \mathrm{~mm}, 7 \mu \mathrm{m}$, Sykam, Eresing, Germany). The flow rate of the buffer solution ( $\mathrm{pH} 3.45-10.85$ ) was set at 0.45 
$\mathrm{mL} / \mathrm{min}$, and that of reagent was set at $0.25 \mathrm{~mL} / \mathrm{min}$. A fluorescence detector $(\mathrm{Ex}=440 \mathrm{~nm}, \mathrm{Em}=570 \mathrm{~nm})$ was used for amino acid detection.

\section{Mineral content}

Mineral content was analyzed in accordance with the Food Codex (Ministry of Food and Drug Safety, 2020). Ten milliliter of nitric acid was added to $0.3 \mathrm{~g}$ of freeze-dried laver sample in a Teflon-coated vessel, and the mixture was dissolved in microwave (MARS, CEM, Matthews, NC, USA). The dissolved solution was diluted to $50 \mathrm{~mL}$ using distilled water and analyzed with an inductively coupled plasma atomic emission spectrometer (Optima 8300, PerkinElmer, Waltham, MA, USA).

\section{Shinorine and porphyra-334 content}

Extraction was performed for $24 \mathrm{~h}$ by adding $200 \mathrm{~mL}$ of $50 \%$ methanol $(\mathrm{MeOH})$ to $3 \mathrm{~g}$ of freeze-dried laver at room temperature. The extract was filtered through a No. 2 filter paper (Whatman, Maidstone, England) to obtain the filtrate. Two hundred milliliter of $50 \% \mathrm{MeOH}$ was added to the residual sample and a second filtrate was obtained via the same protocol. The two filtrates were mixed and concentrated under a vacuum to obtain $50 \% \mathrm{MeOH}$ extract. This extract was dissolved by adding $20 \mathrm{~mL}$ of $\mathrm{MeOH}$ and filtered through a $0.45 \mu \mathrm{m}$ membrane filter (Advantec, Tokyo, Japan). Shinorine and porphyra-334 were analyzed using a HPLC (SPD-M20D, Shimadzu) equipped with a Capcell pak $\mathrm{C}_{18}$ AQ column $(4.6 \times 250 \mathrm{~mm}, 5 \mu \mathrm{m}$, Shiseido, Tokyo, Japan) and a photodiode array (PDA, 190-800 nm) detector. The mobile phase consisted of water containing $0.1 \%$ acetic acid (A) and acetonitrile (B) with using a gradient elution (0-5 min 0\% B; 5-25 min 0-20\% B; 25-30 min 20\% B). The compounds were monitored at $330 \mathrm{~nm}$ and the flow rate of the mobile phase was set at $1 \mathrm{~mL} / \mathrm{min}$. Shinorine and porphyra-334 purified from laver were used as the external standards.

\section{Total phenol content}

In accordance with Son's (2014) method, extraction was performed for $24 \mathrm{~h}$ by adding $50 \mathrm{~mL}$ of distilled water to $2 \mathrm{~g}$ of freeze-dried laver and filtered through a suction filter (No. 2, Whatman, Maidstone, England) to obtain the filtrate. The filtrate was concentrated under reduced pressure and prepared to a concentration of $200 \mathrm{mg} / \mathrm{mL}$ by adding distilled water. Total phenolic content was measured using the Folin-Denis method (Folin and Denis, 1912), which utilizes the principle in which the reduction of the Folin-Ciocalteu's phenol reagent by phenolic compounds generates the molybdenum blue. In other words, $20 \mu \mathrm{L}$ of Folin-Ciocalteu's reagent was added to $20 \mu \mathrm{L}$ of the sample and incubated in a dark room for $3 \mathrm{~min}$. After adding $200 \mu \mathrm{L}$ of $10 \%$ $\mathrm{Na}_{2} \mathrm{CO}_{3}$ to this solution and incubating in a dark room for $15 \mathrm{~min}$, absorbance was measured at $765 \mathrm{~nm}$ using a microplate reader (Infinite M200 PRO, Tecan, Salzburg, Austria). The total phenol content of the sample was quantified from the absorbance value using a standard curve obtained using tannic acid and was expressed as mg tannic acid equivalent per gram of laver sample (mg TAE/g dry wt.).

\section{$\mathrm{ABTS}^{+}$radical-scavenging activity}

The $\mathrm{ABTS}^{+}$radical-scavenging activity of the aqueous laver extract prepared above was measured using the method delineated by Pellegrin et al. (1999). In other words, $5 \mathrm{~mL}$ of $7 \mathrm{mM} \mathrm{ABTS}{ }^{+}$solution was mixed with $88 \mu \mathrm{L}$ of $140 \mathrm{mM}$ potassium persulfate solution and incubated in dark for 14-16 h. Then, absolute ethanol was added to prepare an $\mathrm{ABTS}^{+}$radical solution with an absorbance of $0.70 \pm 0.02$ at $734 \mathrm{~nm} .20 \mu \mathrm{L}$ of the sample solution was mixed with 180 $\mu \mathrm{L}$ of ABTS solution and incubated in dark for $3 \mathrm{~min}$, and absorbance was read at $734 \mathrm{~nm}$ using a microplate reader (Infinite M200 PRO, Tecan). The $\mathrm{ABTS}^{+}$radical-scavenging activity was measured using the equation below with the absorbance values of the non-treated and treated samples. Further, the concentration at $50 \% \mathrm{ABTS}^{+}$radical-scavenging activity $\left(\mathrm{SC}_{50}, \mathrm{mg} / \mathrm{mL}\right)$ was calculated using the free radicalscavenging activity curve by concentration for each sample.

$\mathrm{ABTS}^{+}$radical-scavenging activity (\%)

$=(1-$ Sample absorbance $/$ Control absorbance $) \times 100$

\section{Ferric ion reducing antioxidant power (FRAP)}

FRAP activity was measured using the method proposed by Benzie and Strain (1996). The FRAP reagent was prepared by heating $40 \mathrm{~mL}$ acetate buffer $(300 \mathrm{mM}, \mathrm{pH} 3.6)$ at $37^{\circ} \mathrm{C}$ and mixing with $4 \mathrm{~mL}$ of $10 \mathrm{mM} \mathrm{TPTZ}$ dissolved in $40 \mathrm{mM} \mathrm{HCl}$ and $4 \mathrm{~mL}$ of $20 \mathrm{mM}$ ferric chloride hexahydrate $\left(\mathrm{FeCl}_{3} \cdot 6 \mathrm{H}_{2} \mathrm{O}\right) .20 \mu \mathrm{L}$ of the aqueous laver 
extract was added to $180 \mu \mathrm{L}$ of the prepared FRAP reagent and incubated for $10 \mathrm{~min}$ at $37^{\circ} \mathrm{C}$. Absorbance was measured at $593 \mathrm{~nm}$ using a microplate reader (Infinite M200 PRO, Tecan). The reducing power was computed from these absorbance values using a standard curve for iron (II) sulfate at concentrations of $0.156,0.313,0.625,1.25$, and $2.5 \mathrm{mM}$.

\section{Statistical analysis}

All experiments were conducted three times, and the data were statistically analyzed using IBM SPSS statistics (24, IBM Corp., Armonk, NY, USA). The results were presented as mean and standard deviation. One-way ANOVA and post-hoc test (Scheffe test) were performed to analyze the differences among the samples, and significance was set at $\mathrm{p}<0.05$.

\section{Results and discussion}

\section{Total amino acid content}

Table 1 shows the total amino acid content of laver samples with varying laver varieties and harvest periods. Total amino acid content wss the highest in $P$. yezoensis (PY) harvested in December (PY12, 40,914.26 mg/100 g dry wt.) and January (PY01, 41,009.52 mg/100 g dry wt.), respectively and the lowest in $P$. dentata (PD11, 33,762.75 $\mathrm{mg} / 100 \mathrm{~g}$ dry wt.). Total amino acid content of laver varied

Table 1. Total amino acid content in three laver cultivars harvested at different times

\begin{tabular}{|c|c|c|c|c|c|}
\hline \multirow{2}{*}{ Compounds } & \multicolumn{5}{|c|}{ Contents (mg/100 g dry wt.) } \\
\hline & PD11 ${ }^{1)}$ & PS12 & PY12 & PY01 & PY03 \\
\hline Isoleucine & $1,270.83 \pm 182.04^{\mathrm{b}}$ & $1,469.50 \pm 119.69^{\mathrm{b}}$ & $1,821.87 \pm 52.66^{\mathrm{a}}$ & $1,862.45 \pm 191.40^{\mathrm{a}}$ & $1,404.46 \pm 50.35^{\mathrm{b}}$ \\
\hline Leucine & $2,662.35 \pm 340.85^{\mathrm{b}}$ & $3,039.99 \pm 189.57^{\mathrm{ab}}$ & $3,428.10 \pm 59.36^{\mathrm{a}}$ & $3,478.73 \pm 377.88^{\mathrm{a}}$ & $2,751.09 \pm 48.24^{\mathrm{b}}$ \\
\hline Lysine & $1,863.59 \pm 256.37^{\mathrm{c}}$ & $2,056.51 \pm 160.52^{\mathrm{abc}}$ & $2,289.17 \pm 148.26^{\mathrm{ab}}$ & $2,324.78 \pm 337.43^{\mathrm{a}}$ & $1,902.28 \pm 19.22^{\mathrm{bc}}$ \\
\hline Methionine & $693.28 \pm 78.15^{\mathrm{b}}$ & $572.06 \pm 53.59^{\mathrm{b}}$ & $1,072.20 \pm 105.34^{\mathrm{a}}$ & $968.35 \pm 24.93^{\mathrm{a}}$ & $708.94 \pm 151.11^{\mathrm{b}}$ \\
\hline Phenylalanine & $1,398.19 \pm 175.00^{\mathrm{c}}$ & $1,619.99 \pm 114.96^{\mathrm{bc}}$ & $1,938.14 \pm 48.53^{\mathrm{a}}$ & $1,818.41 \pm 183.78^{\mathrm{ab}}$ & $1,473.65 \pm 10.59^{c}$ \\
\hline Threonine & $1,909.88 \pm 311.16^{\mathrm{a} 4) 5)}$ & $2,141.56 \pm 59.78^{\mathrm{ab}}$ & $2,351.08 \pm 40.42^{\mathrm{a}}$ & $2,332.09 \pm 357.09^{\mathrm{ab}}$ & $1,919.80 \pm 90.20^{\mathrm{b}}$ \\
\hline Valine & $2,235.56 \pm 276.18^{\mathrm{a}}$ & $2,507.00 \pm 168.97^{\mathrm{ab}}$ & $2,896.39 \pm 88.33^{\mathrm{a}}$ & $2,862.54 \pm 338.62^{\mathrm{a}}$ & $2,239.84 \pm 53.92^{\mathrm{b}}$ \\
\hline Total $\mathrm{EAA}^{2)}$ & $12,033.67 \pm 1,540.51^{\mathrm{b}}$ & $13,406.62 \pm 817.57^{\mathrm{b}}$ & $15,796.93 \pm 215.15^{\mathrm{a}}$ & $15,647.36 \pm 1,777.20^{\mathrm{a}}$ & $12,400.05 \pm 259.81^{\mathrm{b}}$ \\
\hline Alanine & $4,338.85 \pm 720.15^{\mathrm{a}}$ & $3,377.89 \pm 247.50^{\mathrm{b}}$ & $3,679.59 \pm 175.36^{\mathrm{ab}}$ & $3,737.37 \pm 399.96^{\mathrm{ab}}$ & $3,302.79 \pm 50.40^{\mathrm{b}}$ \\
\hline Arginine & $2,728.01 \pm 579.28^{\mathrm{a}}$ & $2,966.93 \pm 184.65^{\mathrm{a}}$ & $3,255.8 \pm 290.84^{\mathrm{a}}$ & $3,280.88 \pm 651.37^{\mathrm{a}}$ & $2,579.90 \pm 204.81^{\mathrm{a}}$ \\
\hline Aspartic acid & $3,388.30 \pm 571.55^{\mathrm{a}}$ & $3,823.29 \pm 151.65^{\mathrm{a}}$ & $4,245.11 \pm 163.42^{\mathrm{a}}$ & $4,346.54 \pm 868.94^{\mathrm{a}}$ & $3,490.59 \pm 278.55^{\mathrm{a}}$ \\
\hline Cystine & $35.17 \pm 60.91^{\mathrm{b}}$ & $11.55 \pm 20.00^{\mathrm{b}}$ & $244.6 \pm 63.31^{\mathrm{a}}$ & $190.54 \pm 69.02^{\mathrm{a}}$ & $63.10 \pm 63.84^{\mathrm{b}}$ \\
\hline Glutamic acid & $3,738.66 \pm 754.73^{\mathrm{a}}$ & $3,797.10 \pm 103.29^{\mathrm{a}}$ & $4,177.62 \pm 119.71^{\mathrm{a}}$ & $4,377.63 \pm 750.33^{\mathrm{a}}$ & $3,643.63 \pm 159.75^{\mathrm{a}}$ \\
\hline Glycine & $2,098.91 \pm 374.58^{b}$ & $2,160.16 \pm 100.60^{\mathrm{ab}}$ & $2,630.82 \pm 50.61^{\mathrm{a}}$ & $2,570.99 \pm 396.24^{\mathrm{ab}}$ & $2,095.64 \pm 79.39^{b}$ \\
\hline Histidine & $529.17 \pm 30.71^{\mathrm{a}}$ & $634.78 \pm 167.63^{\mathrm{a}}$ & $660.65 \pm 108.85^{\mathrm{a}}$ & $552.68 \pm 68.07^{\mathrm{a}}$ & $480.33 \pm 75.37^{\mathrm{a}}$ \\
\hline Proline & $1,731.41 \pm 390.01^{\mathrm{a}}$ & $2,062.57 \pm 123.95^{\mathrm{a}}$ & $2,251.63 \pm 339.18^{\mathrm{a}}$ & $2,306.52 \pm 688.38^{\mathrm{a}}$ & $1,783.59 \pm 336.24^{\mathrm{a}}$ \\
\hline Serine & $1,944.08 \pm 345.15^{\mathrm{a}}$ & $2,086.53 \pm 55.21^{\mathrm{a}}$ & $2,305.40 \pm 43.72^{\mathrm{a}}$ & $2,355.39 \pm 411.74^{\mathrm{a}}$ & $1,881.46 \pm 83.09^{\mathrm{a}}$ \\
\hline Tyrosine & $1,196.53 \pm 173.06^{\mathrm{b}}$ & $1,392.86 \pm 124.98^{\mathrm{b}}$ & $1,666.11 \pm 67.02^{\mathrm{a}}$ & $1,643.62 \pm 163.71^{\mathrm{a}}$ & $1,185.44 \pm 49.38^{\mathrm{b}}$ \\
\hline Total $\mathrm{AA}^{3)}$ & $33,762.75 \pm 5,374.50^{b}$ & $35,720.29 \pm 1,495.48^{\mathrm{ab}}$ & $40,914.26 \pm 405.28^{\mathrm{a}}$ & $41,009.52 \pm 6,071.13^{\mathrm{a}}$ & $32,906.54 \pm 859.96^{\mathrm{b}}$ \\
\hline
\end{tabular}

${ }^{1)}$ PD11, $P$. dentata harvested in November; PS12, P. seriata harvested in December; PY12, P. yezoensis harvested in December; PY01, P. yezoensis harvested in January; PY03, $P$. yezoensis harvested in March.

${ }^{2)}$ Total essential amino acid.

${ }^{3)}$ Total amino acid.

4) All values are mean $\pm \mathrm{SD}$ in triplicates.

${ }^{5)}$ Different letters $\left({ }^{a-d}\right)$ in the same column mean significantly different $(p<0.05)$. 
greatly not only according to the variety but also according to the harvest times. In our analysis of the total amino acid contents of PY harvested at different times, the sample collected in March (PY03, 32,906.54 mg/100 g dry wt.) had a lower total amino acid content than the samples collected in December (PY12, 40,914.26 mg/100g dry wt.) and January (PY01, 41,009.52 mg/100 g dry wt.). This is consistent with previous results that the total amino acid contents of laver varies widely according to the growing environment, such as season, habitat, and oceanic conditions (Noda, 1993). In particular, PY had a higher total amino acid contents when harvested in December or January compared to March, suggesting that the abundance of amino acids in the growing environments of December and January is higher than that in March.

The most abundant amino acids in all laver varieties were aspartic acid, glutamic acid, leucine, arginine, and alanine, and these five amino acids accounted for $46.24-50.78 \%$ of the total amino acid content. This is similar to the major amino acid composition of laver reported in the study on dried laver produced in Korea by Lee et al. (1987) and that of the study on the nutritional composition of commercial laver products by Kim et al. (2014). Essential amino acids, such as threonine, valine, methionine, isoleucine, leucine, phenylalanine, and lysine, were some of the major ingredients of laver. The percentage of essential amino acids from the total amino acid content was $37.68-38.61 \%$ in PY,
$37.53 \%$ in PS12, and 35.64\% in PD11, with no marked differences across varieties. Leucine, which is a branched chain amino acid (BCAA), was the most abundant in all laver varieties, and laver contained a rich amount of essential BCAAs other than leucine, such as valine and isoleucine. In other words, BCAA content was 6,395.39$8,203.72 \mathrm{mg} / 100 \mathrm{~g}$ dry wt. in PY, $7,016.49 \mathrm{mg} / 100 \mathrm{~g}$ dry wt. in PS12, and $6,168.74 \mathrm{mg} / 100 \mathrm{~g}$ dry wt. in PD11, accounting for $17.65-21.05 \%$ of total amino acid contents. BCAAs is not only an important regulator of insulin signaling and lipid metabolism but also is the largest storage of muscle proteins that plays a crucial role in protein metabolism (Yao et al., 2016). Particularly, leucine has been reported to enhance protein synthesis and inhibit protein degradation (Kimball and Jefferson, 2001). Laver is an important source of amino acids, and with its rich content of BCAAs, including leucine, valine, and isoleucine, it has benefits in terms of insulin signaling, lipid metabolism, enhanced protein synthesis, and suppressed protein degradation.

\section{Mineral contents}

Table 2 shows the mineral contents of laver samples with varying laver varieties and harvest periods. The major minerals found in laver were calcium $(\mathrm{Ca})$, potassium $(\mathrm{K})$, magnesium $(\mathrm{Mg})$, and sodium $(\mathrm{Na})$, all of which accounted for $96.0-99.2 \%$ of total mineral content. This is consistent

Table 2. Mineral contents in three laver cultivars harvested at different times

\begin{tabular}{|c|c|c|c|c|c|}
\hline \multirow{2}{*}{ Samples } & \multicolumn{5}{|c|}{ Mineral contents (mg/100 g dry wt.) } \\
\hline & $\mathrm{PD}^{1}{ }^{1)}$ & PS12 & PY12 & PY01 & PY03 \\
\hline $\mathrm{K}$ & $887.31 \pm 28.89^{\mathrm{a}}$ & $121.03 \pm 3.37^{\mathrm{d}}$ & $345.83 \pm 14.94^{\mathrm{c}}$ & $372.47 \pm 12.68^{\mathrm{bc}}$ & $463.55 \pm 12.96^{\mathrm{b}}$ \\
\hline $\mathrm{Ca}$ & $493.91 \pm 3.69^{2) \mathrm{a} 3)}$ & $485.57 \pm 4.14^{\mathrm{a}}$ & $363.44 \pm 6.25^{\mathrm{b}}$ & $238.87 \pm 15.28^{\mathrm{c}}$ & $235.32 \pm 7.25^{\mathrm{c}}$ \\
\hline $\mathrm{Mg}$ & $467.50 \pm 10.07^{\mathrm{a}}$ & $492.71 \pm 9.97^{\mathrm{a}}$ & $383.59 \pm 14.61^{b}$ & $357.11 \pm 9.02^{\mathrm{b}}$ & $374.68 \pm 2.52^{\mathrm{b}}$ \\
\hline $\mathrm{Na}$ & $351.96 \pm 10.90^{\mathrm{b}}$ & $279.21 \pm 7.03^{\mathrm{c}}$ & $387.96 \pm 13.28^{\mathrm{a}}$ & $407.83 \pm 11.96^{\mathrm{a}}$ & $272.29 \pm 5.94^{\mathrm{c}}$ \\
\hline $\mathrm{Fe}$ & $7.50 \pm 0.45^{\mathrm{b}}$ & $24.49 \pm 3.47^{\mathrm{a}}$ & $17.51 \pm 2.35^{\mathrm{a}}$ & $20.20 \pm 5.36^{\mathrm{a}}$ & $17.97 \pm 1.82^{\mathrm{a}}$ \\
\hline $\mathrm{Zn}$ & $4.69 \pm 0.20^{\mathrm{c}}$ & $10.55 \pm 0.36^{\mathrm{a}}$ & $5.59 \pm 0.13^{\mathrm{b}}$ & $4.91 \pm 0.37^{\mathrm{bc}}$ & $4.58 \pm 0.08^{\mathrm{c}}$ \\
\hline $\mathrm{Mn}$ & $2.47 \pm 0.06^{\mathrm{a}}$ & $1.28 \pm 0.09^{\mathrm{d}}$ & $1.70 \pm 0.07^{\mathrm{c}}$ & $1.91 \pm 0.09^{\mathrm{bc}}$ & $2.06 \pm 0.03^{\mathrm{b}}$ \\
\hline $\mathrm{Cu}$ & $0.38 \pm 0.02^{\mathrm{d}}$ & $1.56 \pm 0.06^{\mathrm{a}}$ & $1.31 \pm 0.06^{\mathrm{b}}$ & $1.07 \pm 0.05^{\mathrm{c}}$ & $0.94 \pm 0.03^{\mathrm{c}}$ \\
\hline
\end{tabular}

${ }^{1}$ PD11, P. dentata harvested in November; PS12, P. seriata harvested in December; PY12, P. yezoensis harvested in December; PY01, P. yezoensis harvested in January; PY03, P. yezoensis harvested in March.

${ }^{2)}$ All values are mean $\pm \mathrm{SD}$ in triplicates.

${ }^{3}$ Different letters $\left({ }^{a-d}\right)$ in the same column mean significantly different $(p<0.05)$. 
with previous findings that $\mathrm{Ca}, \mathrm{K}, \mathrm{Mg}$, and $\mathrm{Na}$ were the primary minerals found in commercial laver products and PY in different regions (Kim et al., 2014; Mok et al., 2011).

The results of this study showed that the types and contents of minerals varied widely according to variety and harvest time. Although the mineral content could not be compared among laver varieties due to the varying harvest periods, PD11 had the richest $\mathrm{K}$ content, while PS12 had relatively higher amounts of $\mathrm{Ca}$ and $\mathrm{Mg}$. PY had high contents of $\mathrm{Ca}, \mathrm{K}, \mathrm{Mg}$, and $\mathrm{Na}$ at all harvest periods, although the specific contents of minerals differed slightly depending on the harvest period.

Regarding trace minerals in laver, iron $(\mathrm{Fe})$ was found in the highest concentration at $7.50-24.49 \mathrm{mg} / 100 \mathrm{~g}$ dry wt. In particular, Fe content was twofold higher in PS12 (24.49 $\mathrm{mg} / 100 \mathrm{~g}$ dry wt.) and PY (17.51-20.20 mg/100 g dry wt.) than in PD11 (7.50 mg/100 g dry wt.), with no statistically significant difference in Fe content between PS12 and PY ( $>0.05$ ). Fe content also did not statistically significantly differ in PY samples according to the harvest period. Interestingly, zinc $(\mathrm{Zn})$ content varied more greatly according to laver variety and harvest period. $\mathrm{Zn}$ content was more than 1.8 times higher in PS12 (10.55 mg/100 g dry wt.) than in PD11 (4.69 mg/100 g dry wt.) and PY (4.58-5.59 mg/100 $\mathrm{g}$ dry wt.). Zn content in PY was similar to that in PD, and although there were significant differences in $\mathrm{Zn}$ content according to harvest period, the content was very low compared to that in PS12 and thus was insignificant. Manganese (Mn) content was the highest in PD11 (2.47 $\mathrm{mg} / 100 \mathrm{~g}$ dry wt.), while copper $(\mathrm{Cu})$ content was the highest in PS12 (1.56 mg/100 g dry wt.).

Kim et al. (2014) and Jung et al. (2016) reported that mineral contents differ even in the same variety depending on the environment of the farming region. Although the exact order of mineral content differed, they found that the major minerals were $\mathrm{Ca}, \mathrm{K}, \mathrm{Mg}$, and $\mathrm{Na}$, with $\mathrm{Fe}$ being the most abundant trace mineral. Baek et al. (2019) reported that PY and PD differ in their mineral contents, and similar to the results of this study, the major minerals were $\mathrm{Ca}, \mathrm{K}, \mathrm{Mg}$, and $\mathrm{Na}$, with Fe being the most abundant trace mineral. In contrast with our findings, Fe content was 1.7 times higher in PD. This may be attributable to the differences in the farming environments.

\section{Shinorine and porphyra-334 content}

MAAs, mycosporine-derived compounds found in various marine organisms, including red algae, consist of a cyclohexenimine or cyclohexenone ring with various substituents such as amino acids and amino alcohol (Carreto et al., 2011). MAAs have been reported to have antioxidant effects and protective effects against ultraviolet rays and photooxidative stress (Shick et al., 2002; Venkatraman et al., 2019; Ying et al., 2019). Particularly, shinorine and prophyra-334 isolated from microalgae not only protects against cytotoxicity caused by UV irradiation but also suppresses the expression of COX-2, an inflammationrelated gene (Cho et al., 2014; Jung et al., 2014). A recent study reported that laver contains MAAs, including shinorine and porphyra-334 (Ying et al., 2019), and these compounds have surfaced as some of the beneficial components of laver. Thus, the shinorine and porphyra-334 contents of three laver varieties were analyzed via ODS-HPLC. As shown in Table 3, the shinorine content was markedly higher in PD11 $(2,090 \mathrm{mg} / 100 \mathrm{~g}$ dry wt.) harvested in November compared to that of PY (1.56-19.00 $\mathrm{mg} / 100 \mathrm{~g}$ dry wt.) and PS12 (1.62 mg/100 g dry wt.). Further, the porphyra-334 content was also markedly higher in PD11 (3,128 mg/100 g dry wt.) compared to that of PY (3.02-438.31 mg/100 g dry wt.) and PS12 $(2.17 \mathrm{mg} / 100 \mathrm{~g}$ dry wt.). Among PY samples with varying harvest periods, the sample collected in March (PY03) had markedly higher shinorine $(19.00 \mathrm{mg} / 100 \mathrm{~g}$ dry wt.) and porphyra-334 content

Table 3. Shinorine and porphyra-334 contents in three laver cultivars harvested at different times

\begin{tabular}{ccc}
\hline \multirow{2}{*}{ Samples } & \multicolumn{2}{c}{ Content $(\mathrm{mg} / 100$ g dry wt. $)$} \\
\cline { 2 - 3 } & Shinorine & Porphyra-334 \\
\hline PD11 ${ }^{1)}$ & $2,090 \pm 107^{2) a 3)}$ & $3,128 \pm 154^{\mathrm{a}}$ \\
PS12 & $1.62 \pm 0.22^{\mathrm{c}}$ & $2.17 \pm 0.07^{\mathrm{d}}$ \\
PY12 & $1.56 \pm 0.01^{\mathrm{c}}$ & $3.02 \pm 0.11^{\mathrm{d}}$ \\
PY01 & $1.56 \pm 0.01^{\mathrm{c}}$ & $17.02 \pm 0.07^{\mathrm{c}}$ \\
PY03 & $19.00 \pm 0.43^{\mathrm{b}}$ & $438.31 \pm 4.83^{\mathrm{b}}$ \\
\hline
\end{tabular}

${ }^{1)} \mathrm{PD} 11, P$. dentata harvested in November; PS12, $P$. seriata harvested in December; PY12, P. yezoensis harvested in December; PY01, $P$. yezoensis harvested in January; PY03, P. yezoensis harvested in March.

2) All values are mean $\pm \mathrm{SD}$ in triplicates.

${ }^{3)}$ Different letters $\left.{ }^{\mathrm{a}-\mathrm{d}} \mathrm{d}\right)$ in the same column mean significantly different $(\mathrm{p}<0.05)$ 
(438.31 mg/100 g dry wt.) compared to samples collected in December (PY12) and January (PY01). In essence, shinorine and porphyra-334 have various biological activities, including skin protection, anti-inflammatory action, and antioxidant activities, as previously mentioned, and PD that contains large amounts of these compounds is promising as an ingredient for functional food compared to other laver varieties. Furthermore, PY03 had a higher shinorine and porphyra-334 content than PY12 and PY01, so it would be a more useful ingredient in various aspects.

\section{Total phenol content}

Phenolic compounds, such as flavonoids, anthocyans, nignans, and stilbenes, are secondary metabolites widely found in plants (Lin et al., 2016). Phenolic compounds exhibit an array of biological activities, including antioxidant activity, dental caries prevention, hypertension prevention, and anti-cancer effects (Yu et al., 2006). While laver was not a rich source of various phenolic compounds, it has been reported to contain catechol, rutin, catechin, and quercetin (Kazlowska et al., 2010). In addition, it was reported to have increased the total phenol content of steamed fish cake and crispy rice snacks when adding laver powder (Kim et al., 2020a; Kim et al., 2020b). Phenolic compounds are expected to contribute to the health functionalities of laver. Therefore, this study investigated the total phenol content of laver samples from different varieties and harvested at varying periods, and the results are shown in Table 4. By variety, PD11 had the highest total phenolic content (702.99

Table 4. Total phenolic contents in three laver cultivars harvested at different times

\begin{tabular}{cc}
\hline Samples & $\begin{array}{c}\text { Total phenolic contents } \\
(\mathrm{mg} \text { TAE} / 100 \mathrm{~g})\end{array}$ \\
\hline PD11 & $702.99 \pm 4.00^{2) \mathrm{a} 3)}$ \\
PS12 & $50.12 \pm 2.88^{\mathrm{d}}$ \\
PY12 & $184.14 \pm 7.51^{\mathrm{b}}$ \\
PY01 & $136.82 \pm 4.01^{\mathrm{c}}$ \\
PY03 & $144.32 \pm 1.75^{\mathrm{c}}$ \\
\hline
\end{tabular}

\footnotetext{
${ }^{1)} \mathrm{PD} 11, P$. dentata harvested in November; PS12, $P$. seriata harvested in December; PY12, P. yezoensis harvested in December; PY01, $P$. yezoensis harvested in January; PY03, P. yezoensis harvested in March. ${ }^{2)}$ All values are mean $\pm \mathrm{SD}$ in triplicates.

${ }^{3)}$ Different letters $\left({ }^{\mathrm{a}-\mathrm{d}}\right)$ in the same column mean significantly different $(\mathrm{p}<0.05)$.
}

mg TAE/100 g dry wt.), followed by PY (136.82-184.14 mg TAE/100 g dry wt.), and PS12 had the lowest phenol content (50.12 mg TAE/100 g dry wt.). In terms of harvest periods, PY12 had significantly higher phenolic content (184.14 mg TAE/100 g dry wt.) compared to PY01 (136.82 mg TAE/100 g dry wt.) and PY03 (144.32 mg TAE/100 g dry wt.). These results supported that total phenol content of laver harvested in December had a higher total phenol content than laver harvested in January to March (Kang et al., 2018). These results show that the total phenol content of laver varies according to the variety and harvest period. Particularly, PD can be utilized to develop food products due to a higher total phenol content than PS and PY, which enhanced functional ingredients, such as phenolic compounds. However, the structures of these phenolic compounds need to be confirmed even though PD is suggested to contain diverse phenolic compounds, including catechol, rutin, and hesperidin found in PY.

\section{$\mathrm{ABTS}^{+}$radical-scavenging activity and FRAP}

$\mathrm{ABTS}^{+}$radical-scavenging activities of laver extracts were examined by concentration, and the concentrations at $50 \%$ radical-scavenging activity $\left(\mathrm{SC}_{50}\right)$ were computed (Table 5 ). PD11 had the lowest $\mathrm{SC}_{50}(55.40 \mathrm{mg} / \mathrm{mL})$, followed by PY $(68.58-144.51 \mathrm{mg} / \mathrm{mL})$ and PS12 $(192.76 \mathrm{mg} / \mathrm{mL})$, which shows that PD has the highest radical-scavenging potential. In addition, PY samples showed varying levels of $\mathrm{ABTS}^{+}$ radical-scavenging depending on the harvest period. This means that PY12 had the highest radical-scavenging activity

Table 5. $\mathrm{ABTS}^{+}$radical-scavenging activity of three laver cultivars harvested at different times

\begin{tabular}{cc}
\hline Samples & $\begin{array}{c}\mathrm{ABTS}^{+} \text {radical-scavenging activity } \\
\left(\mathrm{SC}_{50}, \mathrm{mg} / \mathrm{mL}\right)\end{array}$ \\
\hline PD11 $^{1)}$ & $55.40 \pm 2.97^{\mathrm{e}}$ \\
PS12 & $192.76 \pm 6.81^{2) \mathrm{a} 3)}$ \\
PY12 & $68.58 \pm 1.70^{\mathrm{d}}$ \\
PY01 & $119.91 \pm 4.43^{\mathrm{c}}$ \\
PY03 & $144.51 \pm 2.11^{\mathrm{b}}$ \\
\hline
\end{tabular}

${ }^{1} \mathrm{PD} 11, P$. dentata harvested in November; PS12, $P$. seriata harvested in December; PY12, P. yezoensis harvested in December; PY01, $P$. yezoensis harvested in January; PY03, P. yezoensis harvested in March. ${ }^{2)}$ All values are mean $\pm \mathrm{SD}$ in triplicates.

${ }^{3)}$ Different letters $\left({ }^{\mathrm{a}-\mathrm{d}}\right)$ in the same column mean significantly different $(\mathrm{p}<0.05)$. 
at $\mathrm{SC}_{50}=68.58 \mathrm{mg} / \mathrm{mL}$, while PY3 had the lowest radicalscavenging activity at $\mathrm{SC}_{50}=144.51 \mathrm{mg} / \mathrm{mL}$. Kim et al. (2015) demonstrated that marine algae with a high total phenolic content also had superior ABTS radical-scavenging activity, which was similar to this study.

FRAP was measured for laver extracts with varying varieties and harvest periods, and the results are shown in Table 6. The FRAP results were similar to the $\mathrm{ABTS}^{+}$ radical-scavenging activities. In other words, PD11 showed the highest $\mathrm{ABTS}^{+}$radical-scavenging activity and also had the highest FRAP $(1.47 \mathrm{mM})$, while PS12 had the lowest FRAP $(0.29 \mathrm{mM})$. Further, the FRAP of PY varied according to the harvest period, similar to the results of $\mathrm{ABTS}^{+}$radical-scavenging activity. PY12 had the highest FRAP $(1.19 \mathrm{mM})$, while there were no significant differences in FRAP between PY01 $(0.75 \mathrm{mM})$ and PY03 $(0.70 \mathrm{mM})$.

Antioxidant in laver include pigments such as chlorophyl and carotenoids as well as polyphenols and porphyrin, and the level of antioxidant activity differs according to the production region and antioxidant compounds (Kang et al., 2018; Oh et al., 2013). PD has superior antioxidant activities to PS and PY and thus is promising as an ingredient for natural antioxidants and health functional products.

In conclusion, we examined the physicochemical properties and antioxidant activities of Pyropia yezoensis (PY), Pyropia seriata (PS), and Pyropia dentata (PD), primarily produced in Jeonnam. PY produced in December (PY12) and January (PY01) had higher total amino acid content $(40,914.26 \mathrm{mg} / 100 \mathrm{~g}$ dry wt.) than PS12 (35,720.29 $\mathrm{mg} / 100 \mathrm{~g}$ dry wt.) and PD $11(33,762.75 \mathrm{mg} / 100 \mathrm{~g}$ dry wt.).

Table 6. Ferric reducing antioxidant power (FRAP) of three laver cultivars harvested at different times

\begin{tabular}{cc}
\hline Samples & FRAP $\left(\mathrm{FeSO}_{4}, \mathrm{mM}\right)$ \\
\hline PD11 & $1.47 \pm 0.05^{2) \mathrm{a} 3}$ \\
PS12 & $0.29 \pm 0.01^{\mathrm{d}}$ \\
PY12 & $1.19 \pm 0.93^{\mathrm{b}}$ \\
PY01 & $0.75 \pm 0.04^{\mathrm{c}}$ \\
PY03 & $0.70 \pm 0.04^{\mathrm{c}}$
\end{tabular}

${ }^{1)} \mathrm{PD} 11, P$. dentata harvested in November; PS12, $P$. seriata harvested in December; PY12, P. yezoensis harvested in December; PY01, $P$. yezoensis harvested in January; PY03, P. yezoensis harvested in March. ${ }^{2)}$ All values are mean $\pm \mathrm{SD}$ in triplicates.

${ }^{3}$ Different letters $\left({ }^{\mathrm{a}-\mathrm{d}}\right)$ within a column are significantly different $(\mathrm{p}<0.05)$.
According to harvest time, PY01 had the highest total amino acid content $(41,009.52 \mathrm{mg} / 100 \mathrm{~g}$ dry wt.), while PY03 had the lowest total amino acid content $(32,906.54 \mathrm{mg} / 100 \mathrm{~g}$ dry wt.). This is consistent with previous reports that the total amino acid content of laver varies greatly according to the growing environment, such as season, habitat, and oceanic conditions. The major minerals found in laver were $\mathrm{Ca}, \mathrm{K}$, $\mathrm{Mg}$, and $\mathrm{Na}$, and $\mathrm{Fe}$ was the most abundant trace mineral (7.50-24.49 mg/100 g dry wt.). Mineral contents also seem to differ according to the variety and harvest period which depend on the environments of the cultivation regions. Shinorine and porphyra-334 contents were markedly higher in PD11 $(2,089.84 \mathrm{mg} / 100 \mathrm{~g}$ dry wt. and 3,127.96 mg/100 g dry wt., respectively) compared to the other two varieties. As shinorine and porphyra-334 have skin-protective, antiinflammatory, and antioxidant effects, PD11 is considered a promising ingredient for functional foods. By the harvest time, the shinorine and porphyra-334 contents were markedly higher in PY03 $(19.00 \mathrm{mg} / 100 \mathrm{~g}$ dry wt. and $438.31 \mathrm{mg} / 100 \mathrm{~g}$ dry wt., respectively) than PY12 or PY01, suggesting that PY harvested in March should be utilized if PY is used as a functional food ingredient. PD11 showed the highest total phenol content $(702.99 \mathrm{TAE} \mathrm{mg} / 100 \mathrm{~g}$ dry wt.), followed by PY (136.82-184.14 TAE $\mathrm{mg} / 100 \mathrm{~g}$ dry wt.), and PS12 (50.12 TAE mg/100 g dry wt.). PD11 also exhibited higher ABTS radical-scavenging activity and FRAP than PS12 and PY, suggesting that it has superior antioxidant activities to the other two varieties.

\section{요 약}

본 연구에서는 전남지역에서 주로 생산되고 있는 잇바디 돌김, 모무늬돌김, 그리고 방사무늬김을 대상으로 이화학적 특성 및 항산화 활성을 조사하였다. 김의 구성아미노산 함량 은 12월과 1월에 채취한 방사무늬김이 $40,914.26 \mathrm{mg} / 100 \mathrm{~g}$ dry wt.의 이상으로 모무늬돌김(PS12, 35,720.29 mg/100 g dry wt.)과 잇바디돌김(PD11, 33,762.75 mg/100 g dry wt.)에 비해 상대적으로 높은 함량이었다. 채취시기가 다른 방사무 늬김의 총 구성아미노산 함량을 비교한 결과, 1 월에 채취한 시료(PY01, 41,009.52 mg/100 g dry wt.)에서 가장 높았던 반면, 3월에 채취한 시료(PY03, 32,906.54 mg/100 g dry wt.) 로 가장 낮았다. 이는 김의 총아미노산 함량이 계절, 생육장 소, 해황 등 생육환경에 따라 그 변동이 심한 것으로 보고된 결과와 일치하였다. 김에 함유된 주요 무기질은 $\mathrm{Ca}, \mathrm{K}, \mathrm{Mg}$, 
$\mathrm{Na}$ 였으며, 미량 무기질은 $\mathrm{Fe}$ 가 7.50-24.49 mg/100 g dry wt 로 가장 높은 함량이었다. 이는 양식지역의 환경에 따라 품종 및 채취시기별로 차이를 보이는 것으로 사료된다. Shinorine 과 porphyra-334는 잇바디돌김(PD11)이 2,090 mg/100 g dry wt., $3,128 \mathrm{mg} / 100 \mathrm{~g}$ dry wt.으로 두 종에 비해 월등히 높은 함량을 보였다. 잇바디돌김은 다른 두 품종에 비해 피부보호, 항염증, 항산화 활성 등의 생리활성을 나타내는 shinorine과 porphyra-334를 다량 함유하고 있어 기능성 식품 소재로의 활용이 기대된다. 채취시기별 방사무늬김의 shinorine과 porphyra-334 함량은 3월에 채취된 방사무늬김(PY03)이 각 각 $19.00 \mathrm{mg} / 100 \mathrm{~g}$ dry wt., $438.31 \mathrm{mg} / 100 \mathrm{~g}$ dry wt.로 12 월, 1 월에 채취된 방사무늬김보다 월등히 높아 방사무늬김을 기능성 식품소재로 사용한다면 이를 이용하는 것이 용이할 것 으로 판단된다. 총폴리페놀 함량은 잇바디돌김(PD11, 702.99 $\mathrm{TAE} \mathrm{mg} / 100 \mathrm{~g}$ dry wt.) > 방사무늬김(PY, 136.82-184.14 $\mathrm{TAE} \mathrm{mg} / 100 \mathrm{~g}$ dry wt.) > 모무늬돌김(PS12, 50.12 TAE $\mathrm{mg} / 100 \mathrm{~g}$ dry wt.) 순서였다. ABTS radical 소거활성과 철환원 력(FRAP) 측정 결과, 잇바디돌김(PD11)은 모무늬돌김(PS12) 와 방사무늬김(PY)에 비해 높은 항산화 활성을 나타냈다.

\section{Conflict of interests}

The authors declare no potential conflict of interest.

\section{ORCID}

$\begin{array}{ll}\text { Won Kim } & \text { https://orcid.org/0000-0002-0293-6211 } \\ \text { Jeong-Yong Cho https://orcid.org/0000-0002-2048-5661 }\end{array}$

\section{References}

Bae SH. The origin and development process of laver culture industry in Korea: 1. Laver culture history till the end of Chosun dynasty. Korean J Fish Aquat Sci, 24, 153-166 (1991)

Baek SY, Kim SJ, Kim DH, Kim MR. Comparison of quality characteristic and antioxidant activity between Porphyra yezoensis and Porphyra dentata in Korea. J Korean Soc Food Sci Nutr, 48, 1233-1243 (2019)

Benzie IFF, Strain JJ. The ferric reducing ability of plasma (FRAP) as a measure of "antioxidant power": The FRAP assay. Anal Biochem, 239, 70-79 (1996)

Berg R, Haenen G, Berg H, Bast A. Applicability of an improved trolox equivalent antioxidant capacity (TEAC) assay for evaluation of antioxidant capacity measurements of mixtures. Food Chem, 66, 511-517 (1999)

Carreto JI, Carignan MO. Mycosporine-like amino acids: Relevant secondary metabolites. Chemical and ecological aspects. Mar Drugs, 9, 387-446 (2011)

Chao PC, Hsu CC, Liu WH. Renal protective effects of Porphyra dentate aqueous extract in diabetic mice. Biomedicine, 4, 14-18 (2014)

Cho MJ, Jung HS, Song MY, Seo HH, Atul K, Suh SS, Lee TK, Moh SH. Effect of sun screen utilizing porphyra334 derived from ocean algae for skin protection. J Korea Acad-Ind Cooper Soc, 15, 4272-4278 (2014)

Folin O, Denis W. On phosphotungastic-phosphomolybdic compounds as color reagents. J Biol Chem, 12, 239-243 (1912)

Fellegrin N, Roberta R, Min Y, Catherine RE. Screening of dietary carotenoids and carotenoid-rich fruit extract for antioxidant activities applying 2,2'-azinobis(3-ethylenbenzo thiazoline-6-sulfonic acid) radical cation decolorization assay. Method Enzymol, 299, 379-389 (1999)

He D, Wu S, Yan L, Zuo J, Cheng Y, Wang H, Liu J, Zhang X, Wu M, Choi JI, Tong H. Antitumor bioactivity of porphyran extracted from Pyropia yezoensis Chonsoo2 on human cancer cell lines. J Sci Food Agric, 99, 6722-6730 (2019)

Inoue N, Yamano N, Sakata K, Nagao K, Hama Y, Yanagita T. The sulfated polysaccharide porphyran reduces apolipoprotein B100 secretion and lipid synthesis in HepG2 cells. Biosci Biotechnol Biochem, 73, 447-449 (2009)

Jang GY, Kim HY, Lee SH, Kang YR, Hwang IG, Woo KS, Kang TS, Lee JS, Jeong HS. Effects of heat treatment and extraction method on antioxidant activity of several medicinal plants. J Korean Soc Food Sci Nutr, 41, 914-920 (2012)

Jeon YS, Park SJ, Choi MK, Kang MH. Oxidation stability of lavers made with garlic-salt and their characteristics during storage. J Korean Soc Food Sci Nutr, 37, 83-89 (2008)

Jo KS, Kim JH, Sin HS (1995) Effect of storage conditions on the oxidative stability of lipid in roasted and roasted-seasoned laver (Porphyra tenera). Korean J Food Soc Technol, 27, 902-908 (1995)

Jung HS, Cho MJ, Seo HH, Atul K, Suh SS, Lee TK, Moh 
SH. Role of shinorine derived from microalgae in skin protection. J Korea Acad-Ind Cooper Soc, 15, 44164422 (2014)

Jung SM, Kang SG, Lee HJ, Son JS, Jeon JH, Shin HW. Proximate composition and mineral content, amino acid of laver based on culture areas. Korean J Environ Ecol, 30, 98-103 (2016)

Kang MG, Jeong MC, Park SK, Lee JW, Cho JH, Eom SH, Huh MK, Kim YM. Analysis of seasonal and regional changes in major food components of raw laver Pyropia sp. Korean J Fish Aquat Sci, 51, 510-517 (2018)

Kazlowska K, Hsu T, Hou C, Yang W, Tsai G. Antiinflammatory properties of phenolic compounds and crude extract from Porphyra dentata. J Ethnopharmacol, 128, 123-130 (2010)

Kim BS, Oh BJ, Lee HI. Comparison of the physicochemical properties and antioxidant activity of steamed fish paste containing seaweeds (sea mustard, laver, sea tangle) powder. J Korean Soc Food Sci Nutr, 49, 1169-1174 (2020a)

Kim JH, Kang HM, Lee SH, Lee JY, Park NY. Antioxidant and $\alpha$-glucosidase inhibition activity of seaweed extracts. Korean J Food Preserv, 22, 290-296 (2015)

Kim KW, Hwang JH, Oh MJ, Kim MY, Choi MR, Park WM. Studies on the major nutritional components of commercial dried lavers (Porphyra yezoensis) cultivated in Korea. Korean J Food Preserv, 21, $702-709$ (2014)

Kim SJ, Baek SY, Lim MR. Quality characteristics and antioxidant activities of rice crispy cereal added with dried laver. Korean J Food Sci Technol, 52, 487-494 (2020b)

Kimball SR, Jefferson LS. Regulation of protein synthesis by branched-chain amino acids. Curr Opin Clin Nutr Metab Care, 4, 39-43 (2001)

Kitano Y, Murazumi K, Duan J, Kurose K, Kobayashi S, Sugawara T, Hirata T. Effect of dietary porphyran from the red alga, Porphyra yezoensis, on glucose metabolism in diabetic KK-Ay mice. J Nutr Sci Vitaminol, 58, 14-19 (2012)

Kwack KS, Kim MS, Jeong NH, Nam KD. N-Acyl amino acids surfactant (part 13) effect of structure on surfactant of sodium salts of $N$-acyl amino acid in aqueous solution. J Korean Appl Sci Technol, 17, 99-104 (2000)

Kwon KO, Ryu DG, Jeong MC, Kang EH, Jang YM, Kwon
JY, Kim JM, Shin IS, Kim YM. Analysis of microbial contaminants and microbial changes during dried-laver Pyropia spp. processing. Korean J Fish Aquat Sci, 51, 8-14 (2018)

Kwon MJ, Nam TJ. Porphyran induces apoptosis related signal pathway in AGS gastric cancer cell lines. Life Sci, 79, 1956-1962 (2006)

Lee EJ, Kim GR, Lee HJ, Kwon JH. Monitoring microbiological contamination, pre-decontamination, and irradiation status of commercial dried laver (Porphyra sp.) products. Korea J Food Sci, 49, 20-27 (2017)

Lee KH, Song SH, Jeong IH. Quality changes of dried lavers during processing and storage 1. Quality evaluation of different grades of dried lavers and its changes during storage. Korean J Fish Aquat Sci, 20, 408-418 (1987)

Lin D, Xiao M, Zhao J, Li Z, Xing B, Li X, Kong M, Li L, Zhang Q, Liu Y, Chen H, Qin W, Wu H, Chen S. An overview of plant phenolic compounds and their importance in human nutrition and management of type 2 diabetes. Molecules, 21, 1374 (2016)

Liu Y, Deng Z, Geng L, Wang J, Zhang Q. In vitro evaluation of the neuroprotective effect of oligoporphyran from Porphyra yezoensis in $\mathrm{PC} 12$ cells. J Appl Phycol, 31, 2559-2571 (2019)

MFDS. Korea Food Code. Ministry of Food and Drug Safety, Seoul, Korea, p 75-148 (2020)

Mohibbullah M, Bhuiyan MMH, Hannan MA, Getachew P, Hong YK, Choi JS, Choi IS, Moon IS. The edible red alga Porphyra yezoensis promotes neuronal survival and cytoarchitecture in primary hippocampal neurons. Cell Mol Neurobiol, 36, 669-682 (2016)

Mok JS, Lee TS, Son KT, Song KC, Kwon JY, Lee KJ, Kim JH. Proximate composition and mineral content of laver Porphyra yezoensis from the Korean coast. Kor J Fish Aquat Sci, 44, 554-559 (2011)

Nguyen TT, Choi YJ, Nguyen THP, Neri TA, Choi BD. Change in the antioxidant activity of roasted seasoned laver Pyropia yezoensis with heat processing and storage. Korean J Fish Aquat Sci, 51, 362-368 (2018)

Noda H. Chemistry of marine algae. In: Science of Marine Algae, Oishi K (Editor), Asakura-Shoten, Tokyo, Japan, p 14-29 (1993)

Oh SJ, Kim JI, Kim HS, Son SJ, Choe EO. Composition and antioxidant activity of dried laver, Dolgim. Korean 
J Food Sci Technol, 45, 403-408 (2013)

Park CK, Kang TJ, Kim KS. The nutritional and functional constituents of laver. Bull Fish Sci Inst Yosu Nat'l Univ, 9, 133-137 (2000)

Qu W, Ma H, Pan Z, Luo L, Wang Z, He R. Preparation and antihypertensive activity of peptides from Porphyra yezoensis. Food Chem, 123, 14-20 (2010)

Ren D, Noda H, Amano H, Nishino T, Nishizawa K. Study on antihypertensive and antihyperlipidemic effects of marine algae. Fish Sci, 60, 83-88 (1994)

Seo HY, Jeong BM. Comparative study of food components and sensory properties of common Porphyra yezoensis and functional Porphyra yezoensis. J Korean Soc Food Sci Nut, 36, 1314-1319 (2007)

Shick JM, Dunlap WC. Mycosporine-like amino acids and related gadusols: Biosynthesis, accumulation, and UVprotective functions in aquatic organisms. Annu Rev Physiol, 64, 223-262 (2002)

Shin DM, An SR, In SK, Koo JG. Seasonal variation in the dietary fiber, amino acid and fatty acid contents of Porphyra yezoensis. Korean J Fish Aquat Sci, 46, 337-342 (2013)

Son SH, Choe EO. Toasting effects on the lipid oxidation, antioxidants, and pigments of dried laver (Porphyra spp.). J Korean Food Sci Technol, 46, 677-681 (2014)

Son SJ. Lipid oxidation, pigment, and antioxidant activity of dried laver (Porphyra seriata) affected by roasting. MS Thesis, Inha University, Korea, p 17-19 (2014)

Tsuge K, Okabe M, Yoshimura T, Sumi T, Tachibana H, Yamada K. Dietary effects of porphyran from Porphyra yezoensis on growth and lipid metabolism of SpragueDawley rats. Food Sci Technol Res, 10, 147-151 (2004)

Ueno M, Cho KC, Isaka S, Nishiguchi T, Yamaguchi K, Kim DK, Oda T. Inhibitory effect of sulphated polysaccharide porphyran (isolated from Porphyra yezoensis) on RANKL-induced differentiation of RAW 264.7 cells into osteoclasts. Phytother Res, 32, 452-458 (2018)
Venkatraman KL, Mehta A. Health benefits and pharmacological effects of Porphyra species. Plant Foods Hum Nutr, 74, 10-17 (2019)

Yanagido A, Ueno M, Jiang Z, Cho KC, Yamaguchi K, Kim DK, Oda T. Increase in anti-inflammatory activities of radical-degraded porphyrans isolated from discolored nori (Pyropia yezoensis). Int J Biol Macromol, 117, 78-86 (2018)

Yao K, Duan Y, Li F, Tan B, Hou Y, Wu G, Yin Y. Leucine in obesity: Therapeutic prospects. Trends Pharmacol Sci, 37, 714-724 (2016)

Ying R, Zhang Z, Zhu H, Li B, Hou H. The protective effect of mycosporine-like amino acids (MAAs) from Porphyra yezoensis in a mouse model of UV irradiationinduced photoaging. Mar Drugs, 17, 470-473 (2019)

Yoshie Y, Suzuki T, Shirai T, Hirano T, Lee EH. Dietary fiber, minerals, free amino acids and fatty acid compositions in dried nori of several culture places in Korea. J Tokyo Univ of Fish, 80, 197-203 (1993)

Yu MH, Im HG, Lee HJ, Ji YJ, Lee IS. Components and their antioxidative activities of methanol extracts from sarcocarp and seed of Zizyphus jujuba var. inermis Rehder. Korean J Food Sci Technol, 38, 128-134 (2006)

Yu X, Zhou C, Yang H, Huang X, Ma H, Qin X, Hu J. Effect of ultrasonic treatment on the degradation and inhibition cancer cell lines of polysaccharides from Porphyra yezoensis. Carbohydr Polym, 117, 650-656 (2015)

Zhang Z, Zhang Q, Wang J, Zhang H, Niu X, Li P. Preparation of the dierent derivatives of the lowmolecular-weight porphyran from Porphyra haitanensis and their antioxidant activities in vitro. Int $\mathrm{J}$ Biol Macromol, 45, 22-26 (2009)

Zhao T, Zhang Q, Qi H, Zhang H, Niu X, Xu Z, Li Z. Degradation of porphyran from Porphyra haitanensis and the antioxidant activities of the degraded porphyrans with different molecular weight. Int J Biol Macromol, 38 , 45-50 (2006) 